\title{
Creating Evaluation Profiles for Games Designed to be Fun: An Interpretive Framework for Serious Game Mechanics
}

\author{
Ulrich, Frank; Helms, Niels Henrik
}

Published in:

Simulation \& Gaming

Link to article, DOI:

$10.1177 / 1046878117709841$

Publication date:

2017

Document Version

Peer reviewed version

Link back to DTU Orbit

Citation (APA):

Ulrich, F., \& Helms, N. H. (2017). Creating Evaluation Profiles for Games Designed to be Fun: An Interpretive Framework for Serious Game Mechanics. Simulation \& Gaming, 48(5), 695-714.

https://doi.org/10.1177/1046878117709841

\section{General rights}

Copyright and moral rights for the publications made accessible in the public portal are retained by the authors and/or other copyright owners and it is a condition of accessing publications that users recognise and abide by the legal requirements associated with these rights.

- Users may download and print one copy of any publication from the public portal for the purpose of private study or research.

- You may not further distribute the material or use it for any profit-making activity or commercial gain

- You may freely distribute the URL identifying the publication in the public portal

If you believe that this document breaches copyright please contact us providing details, and we will remove access to the work immediately and investigate your claim. 


\title{
Creating Evaluation Profiles for Games Designed to be Fun: An Interpretive Framework for Serious Game Mechanics
}

\author{
Frank Ulrich ${ }^{1}$ and Niels Henrik Helms ${ }^{2}$
}

\begin{abstract}
Background. Games can be great pedagogical tools for educators and students. COTS games (commercialoff-the-shelf) are designed for the pure purpose of leisure but can also contain educational value.

Aim. In this paper, we address the potential of COTS games as serious games. We develop an interpretive evaluation framework that can identify the educational value in COTS games.

Application. The presented framework can create evaluative profiles of the learning, social, game, and immersive mechanics of COTS games as educational tools. Moreover, the framework can position COTS games between four intertwined dimensions, namely pedagogical, design, knowledge, and sociotechnical considerations.

Demonstration. To validate the practical application of the interpretive framework, we apply it to a real-world example. Our demonstration reveals the usefulness of the framework.

Conclusions. The framework enables critical reflection on the game mechanics; thereby capturing the complexity of the game mechanics that makes COTS game both educational and fun to play.
\end{abstract}

\section{Keywords}

Serious games, evaluation, interpretive research, game mechanics, education, COTS (commercial-off-theshelf) games.

\section{Introduction}

The purpose of serious games is to be educational and fun (F Bellotti, Kapralos, Lee, Moreno-Ger, \& Berta, 2013). Dedicated serious games are usually designed to deliver educational value mediated through entertaining game mechanics (Francesco Bellotti, Berta, De Gloria, \& Zappi, 2008; Boyle, Connolly, \& Hainey, 2011). However, the main bulk of COTS (commercial-off-the-shelf) games being produced are not designed for the purpose of being educational. Instead, they are designed to be fun (Connolly, Boyle, Macarthur,

\footnotetext{
${ }^{1}$ Technical University of Denmark, Denmark

${ }^{2}$ Vidensemergens APS, Denmark

Corresponding Author:

Frank Ulrich, Technical University of Denmark, Department of Management Engineering, Technology and Innovation Management, Diplomvej, Building 372, Kgs. Lyngby, Denmark.

Email: frul@dtu.dk
} 
Hainey, \& Boyle, 2012). Gaming is a learning activity. You must learn to achieve the game. The question is how learning can be mediated through specific game mechanics, learning profiles, embedded social interaction, and immersion. As Boyle et al. (2011) specify, COTS games such as massively multiplayer online role-playing games (MMORPGs) involve the creation of apprenticeship and communities of practice between players to gradually acquire new problem-solving skills and domain knowledge. The acquired skills and knowledge are then used by players to create strategies that can resolve real-world situations (ibid). For example, Steinkuehler \& Duncan (2008) demonstrates how World of Warcraft gamers would share ideas and use scientific skills to calculate different combinations of character skills. As such, a COTS game designed for the pure purpose of leisure can become highly valuable in a classroom setting. Moreover, by identifying important mechanics, COTS games can help serious game designers build upon existing knowledge ( $F$. Bellotti, Berta, De Gloria, \& Primavera, 2009) or create better serious games that meaningfully combine the mechanics of fun with the mechanics of learning.

Moreover, Arnab et al. (2015) argue for a lack of research addressing evaluation of serious game mechanics. In this paper, we address this shortcoming by presenting an interpretive framework for evaluating the learning potential of COTS games. We define serious game mechanics as techniques, methods, models, and physical installments, which are translated into specific game content that makes the game work in a desired and meaningful way. Hence, this paper explores the serious game mechanics of COTS games. To achieve this aim, we create a multi-dimensional framework that may help designers identify serious games mechanics in COTS games. The framework is based on interpretive research analysis (Walsham, 1993, 1995, 2006), which enables the evaluator to evaluate COTS games as the outside observer that analyzes documentation or notes events as they unfold, or as the involved observer directly engaged in the game as a designer or active player. Correspondently, we ask the following research question:

How can serious game mechanics in COTS games be identified and evaluated using interpretive research analysis?

We structured the paper using a theory building approach followed by an elaborated example to demonstrate the proposed framework (e.g., Avital \& Te'eni, 2009; De Freitas \& Oliver, 2006; Ulrich, Mengiste, \& Müller, 2015). In the remaining paper, we first review the existing literature on interpretive research and serious game evaluation. We then present an interpretive framework for evaluating serious game mechanics in COTS games. Next, we apply the interpretive framework by evaluating a COTS game as the outside 
observer and the involved participant. Finally, we conclude on our experiences with the framework in relation to the implications for research and practice.

\section{Developing an interpretive framework for serious games mechanics}

Interpretive research analysis has long been used in technology studies to understand the complex relationship between technological artifacts, organizations, and the people therein (Walsham, 1993, 1995, 2006). Information systems is a multidisciplinary field that draws on both natural and social science to understand how information artifacts are designed (Hevner, March, Park, \& Ram, 2004). This can include complex information systems such as COTS games. Interpretive research from an Information systems perspective is thus a well-established data collection and analytical approach that game designers can use to understand and identify the complex mechanics of COTS games. Moreover, interpretive research analysis draws on adaptive research (Layder, 1998), where general theory is used to guide design, data collection, analysis, and the end-product of the research. As in interpretive field studies, the evaluation of COTS games can thus be guided by general theory that frames the observed within previous knowledge. This interpretive research approach can enhance the evaluation of COTS games by creating a "sensible theoretical basis to inform the topics and approach of the early empirical work" (Walsham, 1995, p. 76).

The style of involvement in interpretive fieldwork is based on the researcher taking the position of either the outside observer or the involved observer (Walsham, 1995, 2006). The outside observer will have no direct involvement in events or actions occurring in the field whereas the involved observer will actively participate in events or actions taking place during the data collection. Similarly, the interpretive evaluator can take the role of the outside observer when reflecting on COTS game mechanics by analyzing documentation, interviewing game developers, or observing players or game communities. However, the interpretive evaluator can also be an involved observer by being an active participant in the observed game, an active part of a game community, or (from an action research viewpoint) an active participant in the development of the game design. Hence, our interpretive framework is not designed to partake within a specific epistemological or ontological positioning, for example, positivism or subjective idealism (see Walsham, 1995). Instead, we designed the interpretive framework to be adaptive to the empirical evidence at hand.

In the following sections, we review the literature that addresses the evaluation of serious games. We then combine this knowledge with the interpretive research approach into a framework for evaluating serious game mechanics in COTS games. 
At a conceptual level, a serious game design involves creating a system that accounts for a set of integrated dimensions encompassing concept development, game dynamics, technology use, and reduction of complexity (Westera, Nadolski, Hummel, \& Woperels, 2008). In a similar line of research, Arnab et al., (2015) argue that it is important to understand how different game elements offer effective facilitation of learning, as different serious games contain great variation regarding features and learning experiences. For example, a game such as Tetris facilitates problem-solving using an easy-to-use interface and simple game mechanics. However, a pen-and-paper role-playing system such as Pathfinder consists of thousands of pages to facilitate comprehensive expert knowledge, complex game mechanics, rules for social interaction, and an elaborate graphical design that captures the player's imagination.

Evaluation of serious games is a well-covered area in the pedagogical literature (Amory, 2007; Arnab et al., 2015; F Bellotti et al., 2013; Chin, Dukes, \& Gamson, 2009; De Freitas \& Oliver, 2006; Hays, 2005; Mader, Natkin, \& Levieux, 2012; Popescu \& Bellotti, 2012; Westera et al., 2008). For example, F Bellotti, Berta, Gloria, \& Primavera, (2009) used the players own personal constructs (how they create meaning of situations) to evaluate the player experience in video games. In another study, De Freitas \& Oliver, (2006) created a framework to evaluate serious games. The framework consists of four dimensions that address (a) the pedagogic considerations, which involves learning models and approaches; (b) the mode of representation, which addresses level of fidelity, interactivity, and immersion; (c) the learner specification, which is concerned with the learning profiles and the learner's background; and (d) the context, where play and learning takes place.

However, there is a lack of research on the evaluation of serious game mechanics (Arnab et al., 2015). In addition, it is better to enhance existing game concepts that appeal to a wide audience than attempt to force game aspects upon educational tools (F. Bellotti et al., 2009; Francesco Bellotti et al., 2008). Many COTS games do contain educational value. Hence, it is a question of identifying the valuable mechanics in such games that educators can use in the classroom, or serious game designers can transform into effective systems that can facilitate knowledge construction by students. 


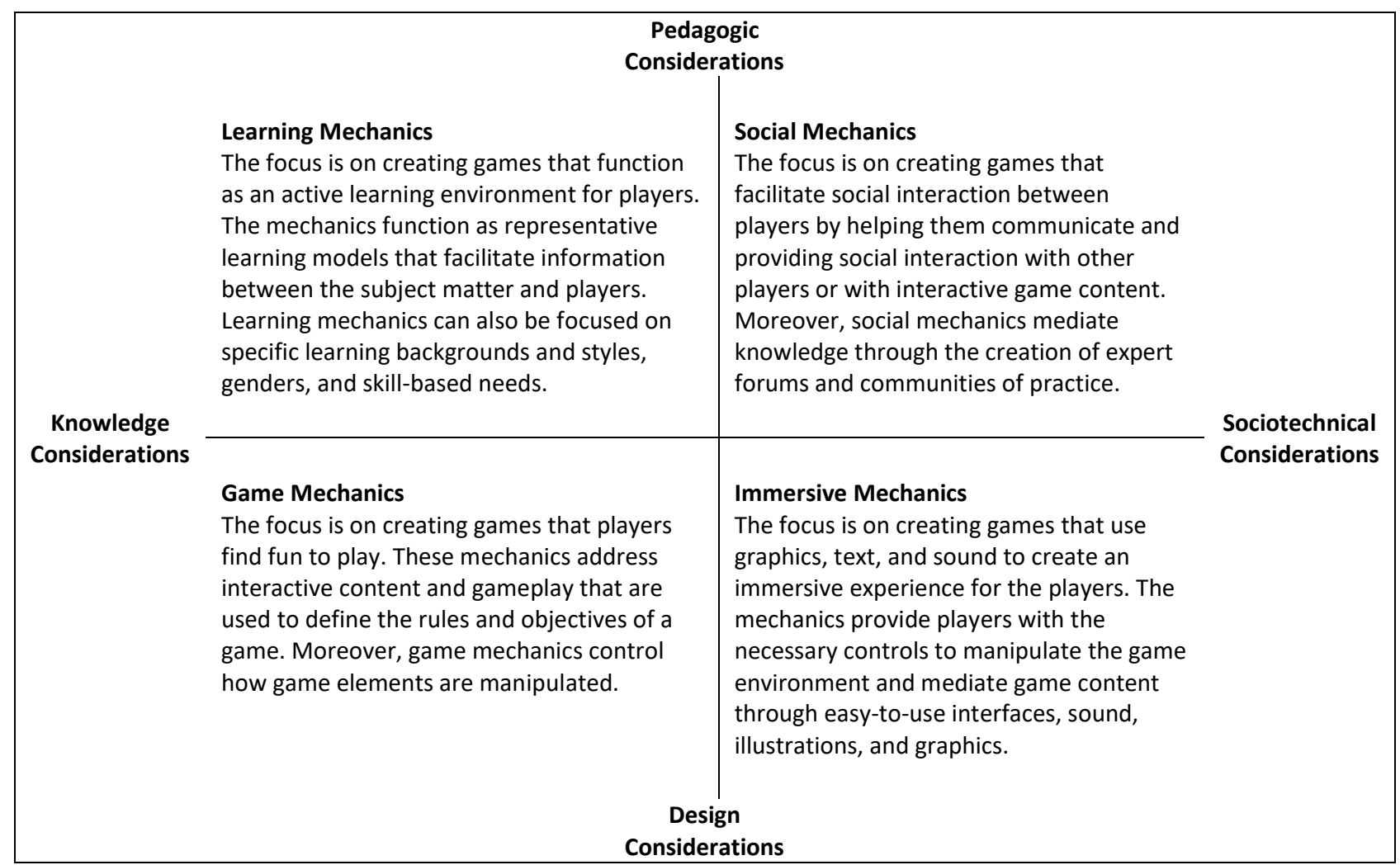

Figure 1. The interpretive framework

This paper presents a framework that addresses this shortcoming by offering an interpretive framework that designers and educators can use to evaluate COTS games (shown in Figure 1). The presented framework involves four core dimensions of serious game mechanics that form the grounding for the interpretive analysis. These four dimensions represent the core serious game mechanics present in most COTS games. Hence, most COTS games, whether they be analog table top games or digital simulation games, will use, combine, and interrelate a range of these four dimensions to function. For example, any COTS game will require the creation of a learning environment to be instructional. It will also require social interaction between the users or the user and the game environment. Moreover, it will require specific game rules that define what to do and what not to do. Finally, it will require technical and visual features to make the game functional and immersive. However, some games do not include all four dimensions. For example, some puzzle games like The Room have limited social interaction with other players or NPC's. In these cases, the interpretive evaluator must (a) identify why the missing mechanics are excluded and (b) what effect (if any) the missing mechanics have on the learning outcome.

The first dimension addresses Learning Mechanics that aim to create an active learning environment for the player. These learning environments are created by translating techniques, methods, and models into mechanics that enhances players' abilities to learn a specific topic. For example, in previous research Arnab 
et al. (2015) list a range of learning mechanics. These mechanics include providing feedback and guidance to players and allowing them to experiment. In addition, games can support different learner groups by having indications for specific learning backgrounds, styles of learning, genders, and skill-based needs (Amory, 2007; De Freitas \& Oliver, 2006). For example, a COTS title such as Project Cars may improve the players driving skills when combined with VR and haptic feedback whereas the Democracy game series can help students to understand the political system.

The second dimension involves Social Mechanics. The focus in social mechanics is placed on creating sociability between players and/or players and the game environment. Social interaction in games is essential for creating learning communities (Amory, 2007). Even though game sociability may result in gender stereotyping, game addiction (Boyle et al., 2011) and social exclusion (Birk et al., 2016), social comparison can also enhance creative thinking skills when people can see what others are doing (Michinov, Jamet, Métayer, \& Le Hénaff, 2014). These mechanics enable players to establish effective communication channels where expert knowledge can be exchanged and where communities of practice can be formed. In such communities of practice, social norms for appropriate behavior can be created, institutionalized, and form actions (Postmes, Spears, \& Lea, 2000). For example, F. Bellotti et al. (2009) created an educational computer game called SeaGame with social mechanics. SeaGame supported social interaction through an embedded instant messenger interface when players' avatars were close to each other, and encouraged collaborative activities by awarding scores, prizes, and in-game content. In SeaGame, players could also interact with virtual characters that provided expert knowledge for specific situations. In a similar line of research, Amory (2007) argue that social networks should be virtualized to allow players to identify their own status within the community. For example, in MMORPGs, players can view the level, equipment, and clan tags of other players and thus determine their social status in the virtual world. Finally, sociability can be identified around the game, namely, in online forums, chatrooms or on video and streaming sites (Boyle et al., 2011). Such sociability should be discounted. By deploying the outside observer, the interpretive evaluator can identify important social mechanics that the game developers did not intend, but are valuable for the pedagogical considerations of the game.

The third dimension concerns Game Mechanics that help to create games that are fun to play. Game mechanics are well addressed in the literature (e.g., Aldrich, 2009; Arnab et al., 2015) and the terminology is used to describe a game's technical and design features (Francesco Bellotti et al., 2008) and mechanics for creating interactive content and gameplay (Aldrich, 2009; Arnab et al., 2015). In this paper, we use game mechanics as a reference for interactive content (e.g., virtual tools and game setting) and gameplay (e.g., the 
setting and type of game), which defines the rules and objectives of a game and enable players to manipulate elements in the game (Djaouti, Alvarez, Jessel, Methel, \& Molinier, 2008). For example, a COTS title such as Battlefield 1 uses a range of game mechanics. These mechanics include rules that govern combat and a set storyline and setting based loosely on historical facts. Moreover, there are game mechanics governing set objectives, competition, and how to progress in the game.

The fourth dimension addresses Immersive Mechanics that provides players with the right amount of fidelity to create an immersive experience. Game designers can create this immersion by designing easy-to-use interfaces, immersive sound effects, and stunning graphics or illustrations. Thus, the immersive mechanics are also concerned with the underlying architecture of the game by addressing, for example, the user interface design and restrictions in the design. Zyda (2005) argues that game designers must understand and advance the use of graphics, sound, and user interfaces in serious games to create an immersive experience that enhances the player's learning. For example, in educational games that require authenticity, a high level of game fidelity will help players transfer knowledge to the real world (Charsky, 2010). In other games, stunning graphics may not be needed to create this immersive experience. The COTS title Minecraft is not visually impressive by today's standards. However, its innovative open world technology creates an immersive experience where the players can freely manipulate the environment. Moreover, tabletop roleplaying games and text-based adventure games can be highly immersive because they are designed to make the player fantasize about the game world.

In addition to the core dimensions, the framework identifies four peripheral dimensions where the mechanics of serious games are intertwined (shown in Figure 2). These peripheral dimensions use the data collection from the core dimensions to create interpretations based on existing knowledge or general theory. They are the pedagogical, design, knowledge, and sociotechnical considerations. We describe the four peripheral dimensions and how evaluators can use them to interpret COTS games. Hence, these intertwined dimensions may help evaluators identify relevant theory when evaluating COTS games, which they can use to interpret the data they have collected. From these interpretations, evaluators can gain a deeper understanding of a game's ability to process knowledge and facilitate learning. 


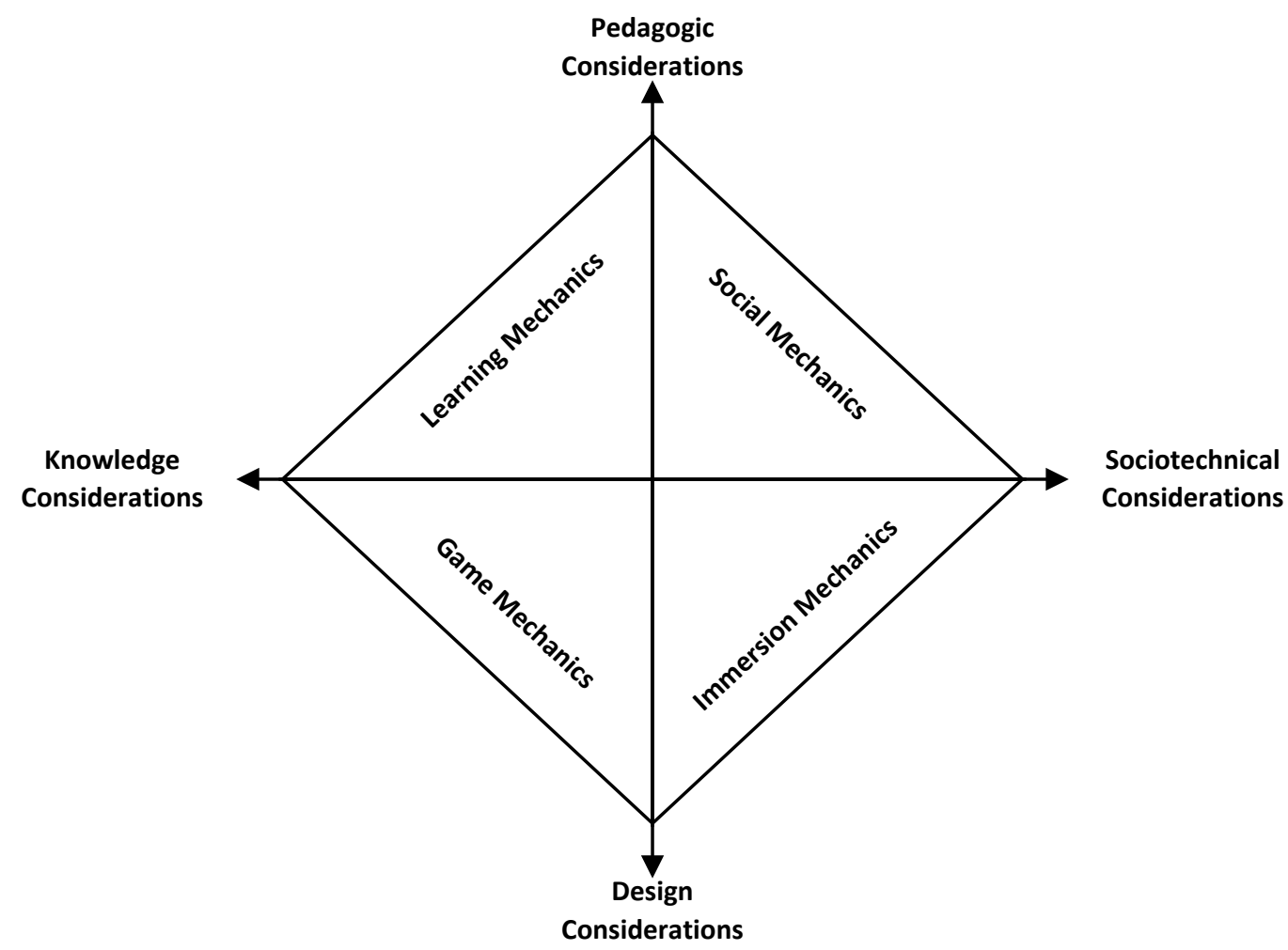

Figure 2: How the core and peripheral dimensions are intertwined.

The pedagogic considerations are concerned with identifying patterns between mechanics that can enhance learning and facilitate social interaction. De Freitas \& Oliver (2006, p. 254) argue that pedagogic considerations should take into account the "processes of learning" by promoting reflections upon "methods, theories, models and frameworks used to support learning practice". This view is strongly aligned with interpretive analysis, where theory guides design, data collection, and analysis while maintaining " $a$ considerable degree of openness to the field data, and a willingness to modify initial assumptions and theories" (Walsham, 1995, p. 76). For example, when preforming interpretive analysis of COTS games, evaluators can reflect on the use of theories. De Freitas \& Oliver (2006) demonstrate that such theories can include activity theory, experimental learning, flexible learning, or constructivist theories.

The design considerations involve identifying patterns between mechanics that make COTS games fun to play, easy to use, visually impressive, and immersive. As with the pedagogic dimension, design considerations should address and reflect upon design frameworks, models, and theories. Evaluators can then obtain new insights by reflecting upon the game and immersive mechanics as individual parts of an artifact (e.g., Lim et al., 2013), for example, by using design science research (Gregor \& Jones, 2007; Peffers, Tuunanen, Rothenberger, \& Chatterjee, 2008; Pries-Heje \& Baskerville, 2008), Gestalt theory (Chang, Dooley, \& Tuovinen, 2002), or theories of participatory design (Kensing \& Blomberg, 1998). For example, evaluators can 
interpret design considerations by asking which theories of design can be applied to the game, who designed the game, how the design approach shaped the game's architecture, and what could be done better.

The knowledge considerations of COTS games are about identifying the knowledge patterns in a game. Hence, the knowledge considerations focus on how the game itself stores, constructs, and facilitates knowledge. The knowledge considerations are strongly connected to the pedagogic considerations. For example, Arnab et al., (2015) argue that learning and game mechanics can facilitate knowledge construction and the acquisition of new skills as the player progresses through the game. Similar to the other peripheral dimensions, interpretations of the knowledge considerations of a COTS game should take into account theories of knowledge facilitation and creation. Such theories can include theories that describe the relationship between tacit and explicit knowledge (e.g., Collins, 2010). Alternatively, knowledge theories could be drawn from other research fields. For example, knowledge management system theories could prove useful for interpreting how a COTS game is designed to retrieve, manage, and apply knowledge for learning (e.g., Alavi \& Leidner, 2001). Therefore, when interpreting the knowledge considerations, evaluators can identify the connection between knowledge facilitation and the mechanics that makes the game fun to play, the relationships between learning and game mechanics through their focus on knowledge construction, how these mechanics are used in other games, and what could be done better.

The sociotechnical considerations of COTS games are balanced around how players use the technology and how their interactions and actions are influenced by the design. When interpreting a game for these considerations, evaluators should take theory into account that recognizes the interaction between people and technology (e.g., Orlikowski \& Gash, 1994; Ulrich et al., 2015). For example, Francesco Bellotti, Berta, De Gloria, D'ursi, \& Fiore (2012) created a highly interactive exploration game that enabled players to visit and explore a city in a 3D space, whereas F. Bellotti et al. (2009) combined social and immersive mechanics in SeaGame, as players could interact with virtual characters in the game. In both games, social and immersive mechanics were highly visible to the players, which increased their feeling of immersion. When interpreting the sociotechnical considerations, evaluators could can the relations between the social and immersive mechanics and their focus, how the game captures the player's attention, how other games use these mechanics, and what could be done better.

In the following, we apply the interpretive framework to a COTS game. Firstly, by creating a set of checklists for serious game evaluation, and secondly, by taking the role of both the outside and involved observer. 


\section{Applying the interpretive framework}

To use the interpretive framework for evaluating mechanics in COTS games, we drew inspiration from a similar evaluative framework by De Freitas \& Oliver (2006). In their seminal paper, they created a checklist that elaborated the content of each of their factors. Similarly, we created a set of checklists, listed in Table 1 and Table 2. The checklists contain 20 questions for the core dimensions and 16 for the peripheral dimensions. Hence, they represent the underlying meaning of the interpretive framework and the considerations of each dimension. The listed questions are aimed at COTS games and are not exhaustive for all games or learning situations. Researchers and practitioners are hence encouraged to adapt these checklists to other settings when using the interpretive framework to evaluate educational games. For example, serious game designers can adapt these checklists to fit into practical design situations, educators can identify specific COTS games to fit into their curriculums, and researchers can identify novel serious game mechanics.

Table 1

Checklist for evaluating across the four core dimensions

\begin{tabular}{|c|c|c|c|}
\hline Learning mechanics & Social mechanics & Game mechanics & Immersion mechanics \\
\hline $\begin{array}{l}\text { Main question: What } \\
\text { mechanics are used to } \\
\text { enhance learning? }\end{array}$ & $\begin{array}{l}\text { Main question: What } \\
\text { mechanics are used to } \\
\text { enhance social interaction? }\end{array}$ & $\begin{array}{l}\text { Main question: What } \\
\text { mechanics are used to } \\
\text { making the game fun to play? }\end{array}$ & $\begin{array}{l}\text { Main question: How are } \\
\text { mechanics used to provide } \\
\text { the player with a more } \\
\text { immersive experience? }\end{array}$ \\
\hline $\begin{array}{l}\text { What are the learning } \\
\text { objectives (e.g., enhancing } \\
\text { social skills, learning new } \\
\text { tools, or obtaining new }\end{array}$ & $\begin{array}{l}\text { How is social interaction } \\
\text { mediated (Non-playing } \\
\text { characters / other players)? }\end{array}$ & $\begin{array}{l}\text { What are the rules of the } \\
\text { game (e.g., turn-based, } \\
\text { puzzle solving, or strategic } \\
\text { dominance)? }\end{array}$ & $\begin{array}{l}\text { What are the game controls } \\
\text { (e.g., joystick, mouse, dices, } \\
\text { figurines)? }\end{array}$ \\
\hline $\begin{array}{l}\text { knowledge of a specific } \\
\text { subject matter)? }\end{array}$ & $\begin{array}{l}\text { What are the social norms? } \\
\text { (e.g., does the game allow } \\
\text { behavior that otherwise }\end{array}$ & $\begin{array}{l}\text { What type of gameplay is } \\
\text { mediated (e.g. first-person }\end{array}$ & $\begin{array}{l}\text { How is the user interface } \\
\text { designed (e.g. cards, paper }\end{array}$ \\
\hline $\begin{array}{l}\text { How is learning mediated } \\
\text { (e.g., tutorial or on-the-fly)? }\end{array}$ & $\begin{array}{l}\text { would be socially } \\
\text { unacceptable)? }\end{array}$ & $\begin{array}{l}\text { shooter, roleplay, or } \\
\text { simulator)? }\end{array}$ & $\begin{array}{l}\text { designed (e.g., cards, paper } \\
\text { sheet, or virtual interface)? }\end{array}$ \\
\hline $\begin{array}{l}\text { What is the learning } \\
\text { environment (e.g., sandbox } \\
\text { or closed classroom setting)? }\end{array}$ & $\begin{array}{l}\text { How is knowledge } \\
\text { communicated between } \\
\text { players (e.g., voice, chat, } \\
\text { and/or online forums)? }\end{array}$ & $\begin{array}{l}\text { What is the game setting } \\
\text { (e.g., fantasy, science fiction, } \\
\text { or realism)? }\end{array}$ & $\begin{array}{l}\text { How is the graphical layout } \\
\text { mediated (e.g., cardboard } \\
\text { tabletop, illustrations in } \\
\text { books, or computer game } \\
\text { engine)? }\end{array}$ \\
\hline $\begin{array}{l}\text { How is the player motivated } \\
\text { to learn? (e.g., penalties or } \\
\text { rewards associated with } \\
\text { learning)? }\end{array}$ & $\begin{array}{l}\text { How is social interaction } \\
\text { rewarded (e.g., prices, scores, } \\
\text { or gifts)? }\end{array}$ & $\begin{array}{l}\text { What in-game tools does the } \\
\text { player have available (e.g., } \\
\text { guns, construction tools, or } \\
\text { sports equipment)? }\end{array}$ & $\begin{array}{l}\text { What are the borders of the } \\
\text { game (e.g., how is movement } \\
\text { restricted and/or what is the } \\
\text { player's view)? }\end{array}$ \\
\hline $\begin{array}{l}\text { Who is the recipient of the } \\
\text { learning? (e.g., specific } \\
\text { profession, gender, or age } \\
\text { group)? }\end{array}$ & $\begin{array}{l}\text { How is social status } \\
\text { virtualized (e.g., players in } \\
\text { MMORPGs can see level and } \\
\text { clan of other players)? }\end{array}$ & $\begin{array}{l}\text { How can game elements be } \\
\text { manipulated (e.g., using } \\
\text { interactive tools)? }\end{array}$ & $\begin{array}{l}\text { How does sound influence } \\
\text { the game (e.g., provides } \\
\text { atmospheric ambiance or } \\
\text { identifying the location of } \\
\text { events)? }\end{array}$ \\
\hline
\end{tabular}


Table 2

Checklist for evaluating across the four peripheral dimensions

\begin{tabular}{|c|c|c|c|}
\hline Pedagogic considerations & Design considerations & Knowledge considerations & $\begin{array}{l}\text { Sociotechnical } \\
\text { considerations }\end{array}$ \\
\hline $\begin{array}{l}\text { Main question: How does the } \\
\text { player(s) learn? } \\
\text { Which learning methods, } \\
\text { models, or theories can be } \\
\text { applied to the game (e.g., } \\
\text { activity theory, experiential } \\
\text { learning, flexible learning, or } \\
\text { constructivist theories)? } \\
\text { Can the same learning } \\
\text { objectives and facilitation be } \\
\text { achieved through other games } \\
\text { (e.g., games that offer the } \\
\text { same type of learning content } \\
\text { or facilitation)? } \\
\text { How can the learning } \\
\text { objectives and facilitation be } \\
\text { transferred to other games } \\
\text { (e.g., implementing the } \\
\text { mechanics in serious games)? }\end{array}$ & $\begin{array}{l}\text { Main question: How is the } \\
\text { game designed? } \\
\text { Which theories of design can } \\
\text { be applied to the game (e.g., } \\
\text { design science, gestalt theory } \\
\text { or participatory design)? } \\
\text { Who designs/designed the } \\
\text { game (e.g., user participation, } \\
\text { modding, closed } \\
\text { development)? } \\
\text { How does the design } \\
\text { approach shape the game's } \\
\text { architecture (e.g., principles } \\
\text { of form and function)? } \\
\text { What could be done better? }\end{array}$ & $\begin{array}{l}\text { Main question: What are the } \\
\text { knowledge relations between } \\
\text { learning and game } \\
\text { mechanics? } \\
\text { Where is the connection } \\
\text { between knowledge } \\
\text { facilitation and fun identified } \\
\text { (e.g., how does specific game } \\
\text { mechanics influence the } \\
\text { knowledge facilitation)? } \\
\text { Where is the connection } \\
\text { between knowledge creation } \\
\text { and fun identified (e.g., do } \\
\text { certain game mechanics also } \\
\text { support knowledge creation)? } \\
\text { Can the same connections be } \\
\text { identified in other games } \\
\text { (e.g., serious games, other } \\
\text { coTS games)? } \\
\text { What could be done better? }\end{array}$ & $\begin{array}{l}\text { Main question: What are } \\
\text { the relations between } \\
\text { social and immersive } \\
\text { mechanics? } \\
\text { Where is the connection } \\
\text { between design and social } \\
\text { interaction identified (e.g., } \\
\text { how do specific immersive } \\
\text { mechanics influence social } \\
\text { interaction)? } \\
\text { Where is the connection } \\
\text { between social norms and } \\
\text { design identified (e.g., how } \\
\text { does the game design } \\
\text { capture institutionalized } \\
\text { social norms)? } \\
\text { Can the same connections } \\
\text { be identified in other } \\
\text { games (e.g., serious games, } \\
\text { other COTS games)? } \\
\text { What could be done } \\
\text { better? }\end{array}$ \\
\hline
\end{tabular}

Rust is an MMORPG developed by Facepunch Studios. Rust follows a new trend in computer games by being an open world survival game, meaning the main objective of the game is to survive the game environment and other players. As the player, you are stranded on a remote island. Your task is then to survive the environment by avoiding being eaten by bears, die from starvation, or being killed by other players. To survive, you can find or research useful items. You can also kill animals and other players, who might want to kill you. Moreover, Rust includes a custom build system known from Minecraft, which enables you to build a shelter that later can be armored to keep other players out.

Walsham (2006) suggest that the interpretive researcher should be pragmatic and analyze the field data while collecting it. We applied a similar approach by continuously identifying themes and issues during the data collection (e.g., from documentation or the player's own interpretations of the game). We then grouped our interpretations within the two checklists listed in Table 3 and 4 . In the role of the outside observer, we interpreted the game documentation (wiki's and videos about the game; information from the developer's homepage). In the role of the involved observer, we rented a Rust server and played the game over three weeks with ten other people, five of whom had never played the game before. We also modded the Rust 
server with add-ons that provided a map to the game, an experience system, an in-game shop, and a notifier system that players could use to see who was online. Our additional role as the server-owner put us in a unique position when the players came to us for help or to solve issues with other players. This role provided us with a unique insight into their interpretations of the game and interactions with other players. Our interpretive evaluation using the outside and involved observers is described in detail below. The results from the core and peripheral dimensions are noted in Table 3 and 4.

The learning mechanics in Rust center on enhancing the players' social, strategy, and architectural skills. Social skills are learned through interaction with other players, whereas strategy and architectural skills are obtained through the in-game architectural system when players build bases in the game. To achieve these learning objectives, a sandbox system is used, where new knowledge is mediated through trial-and-error, e.g., where players build a base that might be raided (attacked) by other players. The attacked players then learn from the experience, i.e., when they have to rebuild their base, and add better strategies using, for example, increased security. To improve security, some players would begin to seek information on the architecture of medieval castles on the internet, while others would interact with more experienced players that could provide them with advice, e.g., for base building. Players are motivated to learn due to the survival aspects of the game. Simply put, if you don't learn to survive, you will die. After playing on several other servers, we also found that the game appeals to a learning group of males aged 13 years and above.

The social mechanics are deeply integrated into Rust. The game differs from other titles in the survival genre by integrating social mechanics in the core of the game. As such, social interaction is mediated through other players using the in-game chat or voice system. However, the in-game voice system only works within a fixed range, similar to a normal conversation. Hence, many players use third-party voice chat such as TeamSpeak to communicate. Moreover, the game encourages social norms that would be completely unacceptable in the real world, as players are encouraged to kill other players, steal their belongings, and destroy their property. However, the game also encourages a situation where survival becomes very aligned with the players' ability to form social bonds and alliances with other players that is displayed, for example, through clan tags. These alliances reward the player by providing security from opposing players, access to resources, and ultimately enable strategic dominance in the game. For example, several of the new players would quit the game in frustration after being raided, only to return later and try to form better alliances. 
Table 3

Interpreting Rust across the four core dimensions

\begin{tabular}{|c|c|c|c|}
\hline Learning mechanics & Social mechanics & Game mechanics & Immersion mechanics \\
\hline $\begin{array}{l}\text { Main question: What } \\
\text { mechanics are used to } \\
\text { enhance learning? }\end{array}$ & $\begin{array}{l}\text { Main question: What } \\
\text { mechanics are used to enhance } \\
\text { social interaction? }\end{array}$ & $\begin{array}{l}\text { Main question: What } \\
\text { mechanics are used to } \\
\text { making the game fun to } \\
\text { play? }\end{array}$ & $\begin{array}{l}\text { Main question: How are } \\
\text { mechanics used to provide } \\
\text { the player with a more } \\
\text { immersive experience? }\end{array}$ \\
\hline $\begin{array}{l}\text { Learning objectives are an } \\
\text { enhancement of social, } \\
\text { strategy, and architectural } \\
\text { skills. }\end{array}$ & $\begin{array}{l}\text { Social interaction is mediated } \\
\text { by other players. } \\
\text { The game does encourage }\end{array}$ & $\begin{array}{l}\text { The game is governed by a } \\
\text { mixture of survival and } \\
\text { strategy rules. }\end{array}$ & $\begin{array}{l}\text { Controls are keyboard and } \\
\text { mouse. }\end{array}$ \\
\hline $\begin{array}{l}\text { Learning happens on-the-fly } \\
\text { by trial-and-error and by } \\
\text { interacting with experienced } \\
\text { players. }\end{array}$ & $\begin{array}{l}\text { social behavior that otherwise } \\
\text { would be unacceptable (e.g., } \\
\text { raiding other player's bases and } \\
\text { stealing their belongings). }\end{array}$ & $\begin{array}{l}\text { The gameplay is a first- } \\
\text { person shooter mixed with } \\
\text { survival and roleplaying } \\
\text { elements. }\end{array}$ & $\begin{array}{l}\text { The user interface is very } \\
\text { similar to existing first-person } \\
\text { shooters. The user interface } \\
\text { also includes a crafting menu. }\end{array}$ \\
\hline $\begin{array}{l}\text { The learning environment is a } \\
\text { sandbox. }\end{array}$ & $\begin{array}{l}\text { A chat and voice system is used } \\
\text { to facilitate communication } \\
\text { between players. Third-party } \\
\text { software such as TeamSpeak is }\end{array}$ & $\begin{array}{l}\text { The game setting is a } \\
\text { pseudo-realistic fantasy } \\
\text { world. }\end{array}$ & $\begin{array}{l}\text { The graphical layout is } \\
\text { mediated through the Unity } \\
\text { game engine. }\end{array}$ \\
\hline $\begin{array}{l}\text { Players are motivated to } \\
\text { learn based on the survival } \\
\text { aspects of the game. }\end{array}$ & $\begin{array}{l}\text { also used. } \\
\text { Social interaction is rewarded } \\
\text { through the creation of }\end{array}$ & $\begin{array}{l}\text { In-game tools include a } \\
\text { large set of weapons, tools, } \\
\text { and deployable equipment. }\end{array}$ & $\begin{array}{l}\text { The players view the world } \\
\text { through a first-person view } \\
\text { and are restricted to an } \\
\text { island. }\end{array}$ \\
\hline $\begin{array}{l}\text { The learning group is mainly } \\
\text { males aged } 13 \text { years and } \\
\text { above. }\end{array}$ & $\begin{array}{l}\text { alliances with other players, } \\
\text { which provides some security } \\
\text { against raids. Social interaction } \\
\text { can also facilitate the exchange } \\
\text { of expert knowledge and goods } \\
\text { between players. } \\
\text { Social status is virtualized } \\
\text { through clan tags. }\end{array}$ & $\begin{array}{l}\text { A building plan and a } \\
\text { hammer are used to build } \\
\text { and upgrade buildings in } \\
\text { the game. Moreover, the } \\
\text { game has a blueprint } \\
\text { system that allows players } \\
\text { to research new content for } \\
\text { the game. Server-side add- } \\
\text { ons can also manipulate the } \\
\text { game. }\end{array}$ & $\begin{array}{l}\text { Sound provides atmosphere } \\
\text { and situational awareness to } \\
\text { the game. }\end{array}$ \\
\hline
\end{tabular}

The game mechanics in Rust includes a set of rules that governs the gameplay. These rules are a combination of survival and strategy rules. The survival rules determine the players' access to resources and technology whereas the strategy rules control building integrity strength and weapon damage. These rules are applied to the gameplay, which is a combination of first-person shooter and survival. Consequently, the player acts within a pseudo-realistic fantasy world governed by the game rules and the player's own actions when they are reduced to cavemen and trying to survive. Hence, during the game, players can obtain various items of equipment that help them survive. These include weapons, tools, and deployable equipment such as boxes, furnaces, turrets, and research and repair tables. Players can also use these tools to manipulate the game environment by building bases, adding defenses, and researching new technology. These game mechanics can also be manipulated server-side by using community-developed add-ons, which changes the rules of the game. For example, we installed an experience plugin and a map that made survival and navigation easier.

The immersive mechanics in Rust are very basic for a computer game. The game is controlled by keyboard and mouse and has a graphical interface that is recognizable from similar MMORPGs such as World of 
Warcraft (see Figure 3). Similar to other MMORPGs, Rust also has a crafting menu where players can create new items they can use in the game. Moreover, players view the game world through a first-person view that is generated by a game engine called Unity. Unity provides the graphical backbone for the game, which enables high-quality physics, lightning, and animations to provide an immersive experience for players. Simultaneously, the sound system provides atmosphere and situational awareness to the players, as they can hear animals and enemies close to their location. For example, when we played the game, the sound system tended to create an extra feeling of paranoia during raids, when we could hear other players moving around in their base. However, players are also restricted through the first-person view and physical borders of the game, which is set on a large island.

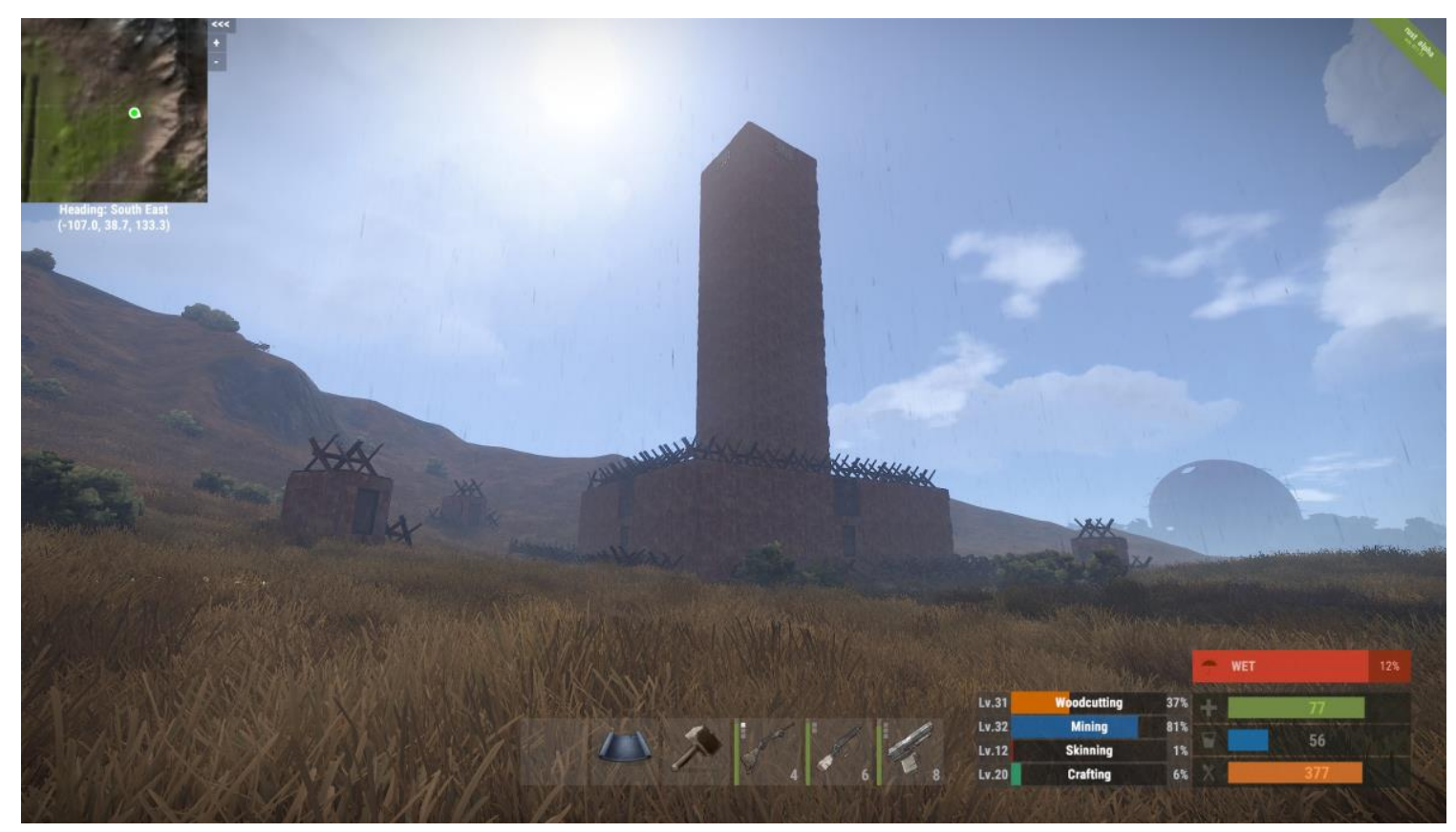

Figure 3. Screen shot from Rust showing the graphical interface and base building.

Next, we interpreted Rust over the four peripheral dimensions (Table 4). In the pedagogic considerations, we identified experimental learning as the appropriate theory to apply to the game. Experimental learning theory argues that learning is driven by conflict and interactions between the person and their experiences in the environment (Kolb \& Kolb, 2005). Moreover, pitting players against each other and making the players know when they fail is commonly used in games (Juul, 2013). This thinking also applies to Rust, where a sandbox-based learning environment and conflicts between players create new knowledge. The social mechanics that aid knowledge creation can easily be transferred to other serious games that wish to apply experimental learning. 
When interpreting Rust according to the design considerations, the game is consistent with a participatory design (see Kensing \& Blomberg, 1998), where the player base participates in the development of the game. This is done through user feedback and an active modification community that adds new value to the game. Thus, the design actors are a mix of the developers that act on player input and the players that provide feedback and autonomously create new modifications for the game. This design approach influences the game architecture as the principles of form and function (see Gregor \& Jones, 2007) change over time. This approach provides new opportunities for creating new game and immersive mechanics, and hence improve the learning experience.

Interpretations related to the knowledge considerations revealed that connections can be identified between the learning environment and specific game mechanics. Gameplay and tool mechanics use the sandbox setting of the game to support experimental learning, where the players can experiment freely with new types of buildings, thus facilitating knowledge on "how to build" and creating new knowledge in the process "when players build". As such, these game mechanics make Rust fun and challenging to play, which increase the potential for a player's knowledge construction. F Bellotti et al. (2013) argue that serious games must be educational and fun to appeal to a wider audience. Rust successfully achieves both these criteria. However, similar game and learning mechanics can also be found in other sandbox games such as Life is Feudal or Minecraft.

Finally, we interpreted Rust based on the sociotechnical considerations. Rust supports social interaction using several immersive mechanics. These include virtualization of social status using clan tags and building construction that can be further enhanced when using third-party modifications. The chat system in the user interface is also an effective mechanic used for social interaction. Moreover, the Unity game engine and user interface mediate social norms by virtualizing the player's actions. For example, raided bases that owners have left will remain standing in the game environment over a long period of time, and the user interface will show the other players who killed them. Previous sociotechnical research by Orlikowski \& Gash (1994) and Ulrich et al. (2015) argues that technology guides and shapes human action when the human actors attempt to make sense and form frames during their interaction with the technology. As such, these virtualizations of human action all help to form social norms of appropriate behavior that guide further action as the players progress in the game. However, it is clear that these connections between social and immersive mechanics are inspired by other games such as Minecraft and DayZ that contain similar connections. In many ways, Rust is a mixture of the two games by extending the social mechanics of the survival genre and combining them with the immersive mechanics of sandbox games such as Minecraft. 
Most modern COTS games have official and unofficial modification capabilities such as level building and scripting tools or even open API's. These tools can help serious game designers and educators to support learning by improving the mechanics of the game. In that regard, Rust could be improved on several fronts. On the pedagogic front, learning in the game could be improved by suggesting different architectural designs when building. Currently, players can only find such architectural designs on the internet. For new players, the integration of architectural suggestions could help them form new knowledge faster than the current trial-and-error model. On the immersive front, Rust could provide better integration of modifications that change the gameplay and game design. Currently, modifications function through a third-party software called Oxide, which enables limited changes to the user interface. An enhanced modification API would allow developers to radically change the game visuals and gameplay. Such modifications could greatly improve the game's potential to be used for educational purposes. On the knowledge considerations of Rust, facilitation of more explicit knowledge would greatly improve the educational capabilities of the game. Currently, Rust is hard to learn, and new players must rely explicitly on expert knowledge from other players and trial and error. However, the speed of learning could be improved by introducing more explicit knowledge such as suggestions on architectural designs (as mentioned above) and better in-game instructions on how to craft items or gather resources. The last suggestion could be implemented using an in-game quest system, where new players progressively obtain new knowledge as they complete quests. On the sociotechnical considerations, Rust is an unusual game, given its social mechanics. Introducing other immersive mechanics could improve this social experience. For example, changing the colors on buildings could signal clan affiliation to other players. Moreover, integrating social and immersive mechanics that use social comparison (e.g., Michinov et al., 2014; Shepherd, Briggs, Reinig, Yen, \& Nunamaker, 1996) could improve social interaction and facilitate competition between the players. 
Table 4

Interpreting Rust across the four peripheral dimensions

\begin{tabular}{|c|c|c|c|}
\hline Pedagogic considerations & Design considerations & Knowledge considerations & Sociotechnical considerations \\
\hline $\begin{array}{l}\text { Inspiration drawn from other } \\
\text { games: We have not } \\
\text { identified the social } \\
\text { mechanics of Rust in other } \\
\text { games. } \\
\text { Inspiration for other games: } \\
\text { The unique social mechanics } \\
\text { of Rust can be transferred to } \\
\text { other games to facilitate } \\
\text { experimental learning. } \\
\text { Suggested improvement: } \\
\text { Including architectural } \\
\text { suggestions to inspire player } \\
\text { created buildings. }\end{array}$ & $\begin{array}{l}\text { Main question: How is the } \\
\text { game designed? } \\
\text { Theory of design: } \\
\text { Participatory design. } \\
\text { Design actors: Mix of closed } \\
\text { development, user } \\
\text { participation, and modding. } \\
\text { The design principles } \\
\text { change over time. } \\
\text { Suggested improvement: } \\
\text { Enabling better integration } \\
\text { of modifications that } \\
\text { radically change the } \\
\text { gameplay and game design. }\end{array}$ & $\begin{array}{l}\text { Main question: What are the } \\
\text { knowledge relations between } \\
\text { the learning and game } \\
\text { mechanics? } \\
\text { Knowledge facilitation and fun: } \\
\text { Gameplay mechanics and tool } \\
\text { mechanics are integrated into a } \\
\text { sandbox setting. } \\
\text { Knowledge creation and fun: } \\
\text { Making the game fun to play } \\
\text { captures the players' attention, } \\
\text { which enables the facilitation } \\
\text { of knowledge creation. } \\
\text { Inspiration drawn from other } \\
\text { games: The same mechanics } \\
\text { can be found in other games in } \\
\text { the survival genre. } \\
\text { Suggested improvement: An in- } \\
\text { game quest system that } \\
\text { facilitates explicit knowledge } \\
\text { for new players. }\end{array}$ & $\begin{array}{l}\text { Main question: What are the } \\
\text { relations between social and } \\
\text { immersive mechanics? } \\
\text { Immersion and social } \\
\text { interaction: The game's } \\
\text { immersive mechanics } \\
\text { supports social interaction } \\
\text { through virtualization of } \\
\text { social status and a chat } \\
\text { system. } \\
\text { Social norms and immersion: } \\
\text { The design mediates social } \\
\text { norms by virtualizing the } \\
\text { player's actions. } \\
\text { Inspiration drawn from other } \\
\text { games: The same } \\
\text { connections can be found in } \\
\text { Minecraft and Dayz. } \\
\text { Suggested improvement: } \\
\text { Better integration of clan } \\
\text { affiliation and use of social } \\
\text { comparison mechanics. }\end{array}$ \\
\hline
\end{tabular}

\section{Conclusion}

Evaluating games for their learning potential is well-covered in the existing pedagogical literature. However, there is a growing need for evaluation frameworks that take into account the serious game mechanics in COTS games. Moreover, interpretive research analysis can prove fruitful when evaluating the mechanics of COTS games for their learning potential.

In this paper, we addressed this shortcoming in the existing literature by bridging interpretive research analysis with state-of-the-art knowledge on serious game evaluation. The result was an interpretive framework that can evaluate COTS games based on four core dimensions of learning, social, game, and immersive mechanics. Moreover, the interpretive framework provides evaluators with the ability to make theoretical reflections across four peripheral dimensions that cover the pedagogic, knowledge, sociotechnical, and design considerations.

By using the interpretive research approach, both researchers and practitioners are provided a flexible and pragmatic tool to evaluate COTS games, where they can take on the role of the outside observer or the involved observer, or both. By taking on these roles, they can create in-depth profiles of COTS games that 
provide information for further game development by identifying important relationships between different mechanics. Moreover, interpretively evaluating CTOS games can provide another benefit by identifying novel serious game mechanics that can provide educational value. The same applies when debriefing on the learning experience, where educators and learners reflect on the game experience and turn it into learning (Crookall, 2010). Combining the presented framework with debriefing may provide fresh insights to the overall learning experience when using a COTS game. Continuous debriefing can also be added to COTS games as a modification, which is an avenue for future research. Consequently, the framework enables researchers, educators and learners to critically reflect on the game mechanics and in the process, capture the complexity of the serious game mechanics that can make a COTS game both educational and fun to play.

However, it was our experience that acting as the involved observer provided more in-depth interpretations of the game we evaluated. Simply put, we were able to extract more information about the game mechanics when we played the game and interacted with other players. The shortcoming of the outside observer was mainly due to the lack of available documentation. Future research can, to a larger extent, deploy the outside observer by using our framework to create interpretive profiles of COTS games when they contain an extended library of documentation (e.g., pen-and-paper roleplaying games such as Pathfinder). In such situations, the outside observer can be combined with textual analysis to create more in-depth profiles. Similar research in the information systems field has used similar frameworks to create cultural profiles from documentation (Muller \& Ulrich, 2015; Müller, Ulrich, \& Nielsen, 2014). As such, comparable text analysis approaches could be applied to this framework by identifying the relevant keywords for each core dimension. Moreover, the involved researcher can introduce interpretation bias from the evaluators own experiences. Using textual analysis in the initial stages of the evaluation could reduce potential interpretation bias by applying a more positivistic approach (e.g., Walsham, 1995). Even though this paper includes 36 questions for interpretations, the framework could be further iterated. For example, other future research could address specific and known serious game mechanics and their placements within the core dimensions. Such a toolkit would especially help practitioners to create interpretive profiles of games they wish to use in the classroom or use as inspiration for novel serious game designs.

\section{Declaration of Conflicting Interests}

The authors declared no potential conflicts of interest with respect to the research, authorship, and/or publication of this article. 


\section{Funding}

The authors received no financial support for the research, authorship, and/or publication of this article.

\section{References}

Alavi, M., \& Leidner, D. E. (2001). Knowledge Management and Knowledge Systems : Conceptual Foundations and Research Issue. MIS Quarterly, 25(1), 107-136. https://doi.org/10.2307/3250961

Aldrich, C. (2009). The Complete Guide to Simulations \& Serious Games: How the Most Valuable Content will be Created in the Age beyond Gutenberg to Google. John Wiley \& Sons.

Amory, A. (2007). Game Object Model Version II: A Theoretical Framework for Educational Game Development. Educational Technology Research and Development, 55(1), 51-77. https://doi.org/10.1007/s11423-006-9001-x

Arnab, S., Lim, T., Carvalho, M. B., Bellotti, F., De Freitas, S., Louchart, S., ... De Gloria, A. (2015). Mapping Learning and Game Mechanics for Serious Games Analysis. British Journal of Educational Technology, 46(2), 391-411. https://doi.org/10.1111/bjet.12113

Avital, M., \& Te'eni, D. (2009). From Generative Fit to Generative Capacity: Exploring an Emerging Dimension of Information Systems Design and Task Performance. Information Systems Journal, 19(4), 345-367. https://doi.org/10.1111/j.1365-2575.2007.00291.x

Bellotti, F., Berta, R., De Gloria, A., D'ursi, A., \& Fiore, V. (2012). A Serious Game Model for Cultural Heritage. Journal on Computing and Cultural Heritage, 5(4), 1-27. https://doi.org/10.1145/2399180.2399185

Bellotti, F., Berta, R., De Gloria, A., \& Primavera, L. (2009). Enhancing The Educational Value of Video Games. Computers in Entertainment, 7(2), 1. https://doi.org/10.1145/1541895.1541903

Bellotti, F., Berta, R., De Gloria, A., \& Zappi, V. (2008). Exploring Gaming Mechanisms to Enhance Knowledge Acquisition in Virtual Worlds. Proceedings of the 3rd International Conference on Digital Interactive Media in Entertainment and Arts - DIMEA '08, 77. https://doi.org/10.1145/1413634.1413653

Bellotti, F., Berta, R., Gloria, A. De, \& Primavera, L. (2009). Player Experience Evaluation: An Approach based on the Personal Construct Theory. In Entertainment Computing - ICEC 2009. Paris, France: Springer Berlin Heidelberg. https://doi.org/10.1007/978-3-642-04052-8_11

Bellotti, F., Kapralos, B., Lee, K., Moreno-Ger, P., \& Berta, R. (2013). Assessment in and of Serious Games: An Overview. In In Advances in Human-Computer Interaction Volume 2013 (Vol. 2013, pp. 1-12). https://doi.org/10.1155/2013/136864

Birk, M. V., Buttlar, B., Bowey, J. T., Poeller, S., Thomson, S. C., Baumann, N., \& Mandryk, R. L. (2016). The 
Effect s of Social Exclusion on Play Experience and Hostile Cognitions in Digital Games. In Proceedings of the SIGCHI Conference on Human Factors in Computing Systems (CHI'2016) (pp. 3007-3019). San Jose, CA, USA: ACM. https://doi.org/10.1145/2858036.2858061

Boyle, E., Connolly, T. M., \& Hainey, T. (2011). The Role of Psychology in Understanding the Impact of Computer Games. Entertainment Computing, 2(2), 69-74. https://doi.org/10.1016/j.entcom.2010.12.002

Chang, D., Dooley, L., \& Tuovinen, J. E. (2002). Gestalt Theory in Visual Screen Design - A New Look at an Old Subject. In Proceedings of the Seventh world conference on computers in education conference on Computers in education: Australian topics (Vol. 8, pp. 5-12). Retrieved from http://dl.acm.org/citation.cfm?id=820062

Charsky, D. (2010). From Edutainment to Serious Games: A Change in the Use of Game Characteristics. Games and Culture, 5(2), 177-198. https://doi.org/10.1177/1555412009354727

Chin, J., Dukes, R., \& Gamson, W. (2009). Assessment in Simulation and Gaming: A Review of the Last 40 Years. Simulation \& Gaming, 40(9), 553-568. https://doi.org/10.1177/1046878109332955

Collins, H. (2010). Tacit and Explicit Knowledge. Chicago: University of Chicago Press.

Connolly, T. M., Boyle, E. A., Macarthur, E., Hainey, T., \& Boyle, J. M. (2012). A Systematic Literature Review of Empirical Evidence on Computer Games and Serious Games. Computers \& Education, 59(2), 661686. https://doi.org/10.1016/j.compedu.2012.03.004

Crookall, D. (2010). Serious Games, Debriefing, and Simulation/Gaming as a Discipline. Simulation \& Gaming, 41(6), 898-920. https://doi.org/10.1177/1046878110390784

De Freitas, S., \& Oliver, M. (2006). How can Exploratory Learning with Games and Simulations within the Curriculum be most Effectively Evaluated? Computers and Education, 46(3), 249-264. https://doi.org/10.1016/j.compedu.2005.11.007

Djaouti, D., Alvarez, J., Jessel, J.-P., Methel, G., \& Molinier, P. (2008). A Gameplay Definition through Videogame Classification. International Journal of Computer Games Technology, 2008, 1-7. https://doi.org/10.1155/2008/470350

Gregor, S., \& Jones, D. (2007). The Anatomy of a Design Theory. Journal of the Association for Information Systems, 8(5), 312-335. Retrieved from http://aisel.aisnet.org/jais/vol8/iss5/19/

Hays, R. T. (2005). The Effectiveness of Instructional Games: A Literature Review and Discussion. Naval Air Warfare Center Training Systems Division. https://doi.org/citeulike-article-id:3089090 Hevner, A. R., March, S. T., Park, J., \& Ram, S. (2004). Design Science in Information Systems Research. MIS Quarterly, 28(1), 75-105. Retrieved from http://dl.acm.org/citation.cfm?id=2017217 Juul, J. (2013). The Art of Failure: An Essay on the Pain of Playing Video Games. MA: MIT Press. 
Kensing, F., \& Blomberg, J. (1998). Participatory Design: Issues and Concerns. Computer Supported Cooperative Work (CSCW), 7(1993), 167-185. https://doi.org/10.1023/A:1008689307411

Kolb, A. Y. K. D. A., \& Kolb, D. a. (2005). Learning Styles and Learning Spaces: Enhancing Experiential Learning in Higher Education. Academy of Management Learning \& Education, 4(2), 193-212. https://doi.org/10.5465/AMLE.2005.17268566

Layder, D. (1998). Sociological Practice - Linking Theory and Practice. London: Sage Publications Ltd.

Lim, T., Louchart, S., Suttie, N., Ritchie, J. M., Aylett, R. S., Stănescu, I. A., ... Moreno-Ger, P. (2013). Strategies for Effective Digital Games Development and Implementation. In Cases on Digital GameBased Learning: Methods, Models, and Strategies (pp. 168-198). Hershey, PA: Information Science Reference. https://doi.org/10.4018/978-1-4666-2848-9.ch010

Mader, S., Natkin, S., \& Levieux, G. (2012). How to Analyse Therapeutic Games: The Player/Game/Therapy Model. In Entertainment Computing-ICEC 2012 (pp. 193-206). https://doi.org/10.1007/978-3-642$33542-6$

Michinov, N., Jamet, E., Métayer, N., \& Le Hénaff, B. (2014). The Eyes of Creativity: Impact of Social Comparison and Individual Creativity on Performance and Attention to Others' Ideas during Electronic Brainstorming. Computers in Human Behavior, 42, 57-67. https://doi.org/10.1016/j.chb.2014.04.037 Muller, S. D., \& Ulrich, F. (2015). The Competing Values of Hackers: The Culture Profile that Spawned the Computer Revolution. In Proceedings of the 48th Annual Hawaii International Conference on System Sciences (HICSS 48) (pp. 3434-3443). Kauai, Hawaii, USA: IEEE. https://doi.org/10.1109/HICSS.2015.413

Müller, S. D., Ulrich, F., \& Nielsen, P. A. (2014). When Process is Getting in the Way of Creativity and Innovation. In 2014 47th Hawaii International Conference on System Sciences (pp. 221-229). IEEE. https://doi.org/10.1109/HICSS.2014.36

Orlikowski, W. J., \& Gash, D. C. C. (1994). Technological Frames - Making Sense of Information Technology in Organizations. ACM Transactions on Information Systems, 12(2), 174-207. https://doi.org/10.1145/196734.196745

Peffers, K., Tuunanen, T., Rothenberger, M. a., \& Chatterjee, S. (2008). A Design Science Research Methodology for Information Systems Research. Journal of Management Information Systems, 24(3), 45-77. https://doi.org/10.2753/MIS0742-1222240302

Popescu, M., \& Bellotti, F. (2012). Approaches on Metrics and Taxonomy in Serious Games. In Proceedings of The 8th International Scientific Conference - eLearning and Software for Education (pp. 351-358). Bucharest, Romania. https://doi.org/10.5682/2066-026X-12-171

Postmes, T., Spears, R., \& Lea, M. (2000). The Formation of Group Norms in Computer-Mediated 
Communication. Human Communication Research, 26(3), 341-371. https://doi.org/10.1111/j.14682958.2000.tb00761.x

Pries-Heje, J., \& Baskerville, R. (2008). The Design Theory Nexus. MIS Quarterly, 32(4), 731-755. Retrieved from http://dl.acm.org/citation.cfm?id=2017405

Shepherd, M. M., Briggs, R. O., Reinig, B. A., Yen, J., \& Nunamaker, F. J. (1996). Invoking Social Comparison to Improve Electronic Brainstorming: Beyond Anonymity. Journal of Management Information Systems, 12(3), 155-170. https://doi.org/10.1080/07421222.1995.11518095

Steinkuehler, C., \& Duncan, S. (2008). Scientific habits of mind in virtual worlds. Journal of Science Education and Technology, 17(6), 530-543. https://doi.org/10.1007/s10956-008-9120-8

Ulrich, F., Mengiste, S. A., \& Müller, S. D. (2015). Informal Evaluation and Institutionalization of Neoteric Technology Ideas: The Case of Two Danish Organizations. Communications of the Association for Information Systems, 37(1), 949-974. Retrieved from http://www.scopus.com/inward/record.url?eid=2-s2.084948777660\&partner ID $=40 \& m d 5=490 d 1 b 3 d 378 d 6 e 1418 a 32 e 5 a 8 c 42 e 621$

Walsham, G. (1993). Interpreting Information Systems in Organizations. Chichester: Wiley. Walsham, G. (1995). Interpretive Case Studies in IS Research: Nature and Method. European Journal of Information Systems, 4(2), 74-81. https://doi.org/10.1057/ejis.1995.9

Walsham, G. (2006). Doing Interpretive Research. European Journal of Information Systems, 15(3), 320330. https://doi.org/10.1057/palgrave.ejis.3000589

Westera, W., Nadolski, R. J., Hummel, H. G. K., \& Woperels, I. G. J. H. (2008). Serious Games for Higher Education: A Framework for Reducing Design Complexity. Journal of Computer Assisted Learning, 24, 420-432. https://doi.org/10.1111/j.1365-2729.2008.00279.x

Zyda, M. (2005). From Visual Simulation to Virtual Reality to Games. Computer, 38(9), 25-32. https://doi.org/10.1109/MC.2005.297 


\section{Author Biographies}

Frank Ulrich is a post-doctoral researcher at The Technical University of Denmark. His research focuses on evaluation and IT-supported innovation.

Contact: frul@dtu.dk

Niels Henrik Helms is an independent researcher. His research focuses on ict-development, innovation and didactic design. He has been associate professor at University of Southern Denmark, head of research and docent at University College Zealand. He is the founder and manager of Vidensemergens APS.

Contact: nhh@vidensemergens.dk 